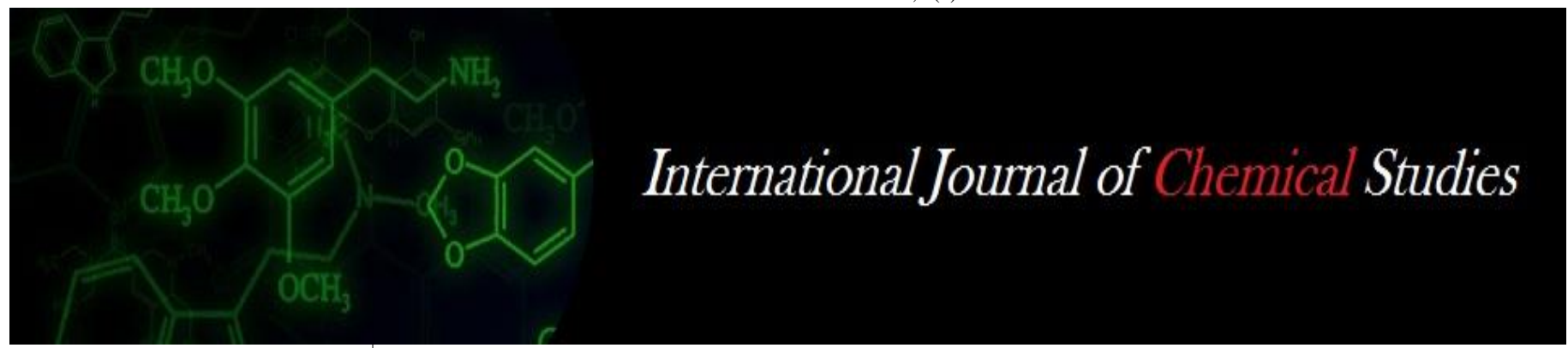

P-ISSN: 2349-8528

E-ISSN: 2321-4902

www.chemijournal.com

IJCS 2020; 8(4): 1836-1840

(C) 2020 IJCS

Received: 09-05-2020

Accepted: 10-06-2020

Ananya Ghosh

Department of Agronomy, Palli Siksha Bhavana, Visva-Bharati, Sriniketan, West Bengal, India

\section{Snehangsu Das}

Department of Plant Protection Palli Siksha Bhavana, Visva-

Bharati, Sriniketan, West

Bengal, India

\section{Md Hasim Reja}

Department of Agronomy,

Bidhan Chandra Krishi

Viswavidyalaya, Mohanpur,

Nadia, West Bengal, India

Swapan Kumar Maity

Department of Agronomy, Palli

Siksha Bhavana, Visva-Bharati,

Sriniketan, West Bengal, India

Corresponding Author:

Ananya Ghosh

Department of Agronomy, Palli

Siksha Bhavana, Visva-Bharati,

Sriniketan, West Bengal, India

\section{Evaluation of rice hybrids in terms of growth, productivity and grain quality under system of Rice Intensification}

\author{
Ananya Ghosh, Snehangsu Das, Md Hasim Reja and Swapan Kumar \\ Maity
}

DOI: https://doi.org/10.22271/chemi.2020.v8.i4s.9894

\begin{abstract}
A field experiment was conducted at Palli Siksha Bhavana, Visva-Bharati, West Bengal to study the performance of five rice hybrids namely 6129 Gold, Tej Gold, 6444 Gold, Prima Gold and PHB 71 in terms of growth, productivity and grain quality under System of Rice Intensification (SRI) during kharif season. Observations revealed that 6129 Gold recorded highest hills $\mathrm{m}^{-2}$ (17.3), no. of panicles $\mathrm{m}^{-2}$ (215.5) and no. of filled grain per panicle (212.4). But owing to least 1000 grain weight $(22.6 \mathrm{~g})$ compared to other hybrid rice cultivars, 6129 Gold achieved lower grain yield (5.6 t ha $\left.{ }^{-1}\right)$. By accounting higher 1000 grain weight $(25 \mathrm{~g})$ and other yield attributing characters, Prima Gold performed best in terms of grain yield $\left(6.9 \mathrm{t} \mathrm{ha}^{-1}\right)$. Besides yield and yield attributing characters, grain quality (hulling, milling and head rice recovery) was also better in Prima Gold. Considering all the observations it can be concluded that Prima Gold and 6444 Gold performed better in moisture striven red lateritic zone of West Bengal under SRI.
\end{abstract}

Keywords: Growth attributes, grain quality, hybrid rice, SRI, yield

\section{Introduction}

Rice can be expressed as life blood for Asian population as the primary food security of 80\% people (Kabir 2007) ${ }^{[9]}$. From $43.19 \mathrm{~m}$ ha rice area India has produced $110.15 \mathrm{~m}$ tonnes rice with a productivity of about $2550 \mathrm{~kg} \mathrm{ha}^{-1}$ (DES, 2018) ${ }^{[3]}$. To meet the over helming demand of growing population, the production must be uplifted. As the natural resources are limited the only option left to provide food and nutritional security is to increase productivity per unit area. But unfortunately the challenge still persists after 50 years of green revolution.Cultivation of rice through traditional method involved lots of inputs and not an environment feasible option. Water management is a prime concern in rice cultivation as it is a limited resource in India today. Scientists are now-a-days advocate per drop more crop.Increase production with less utilization of natural resources, specifically water, is a great concern for today's agriculture. Among the various rice cultivation practices System of Rice Intensification (SRI) is one of the most energy efficient one (Ghosh et al., 2019) ${ }^{[6]}$. It appears to be a good alternative of rice cultivation, that offers the opportunity to boost rice yield with less external inputs like water, seed, nutrients, pesticides etc. (Stoop et al., 2002; Uphoff and Randriamiharisoa 2002) ${ }^{[16,19]}$, improves soil health/quality and protects the environment substantially (Satyanarayana et al., 2007) ${ }^{[15]}$. With sustainable management practices, varieties should be selected which have high yield potentiality. Hybrid rice has a yield advantage of about10-40\% over existing high yielding varieties (Wanjari et al., 2006) ${ }^{[22]}$. In this context hybrid rice cultivation under SRI may be a boon to boost rice yield with limited resources, as hybrid rice offers more yield advantage by adoption of SRI (Devi et al., 2009, Verma et al., $2014)^{[4,21]}$

\section{Materials and Methods}

The experiment was conducted during kharif (rainy) season of 2015 at Agricultural Farm $\left(23^{\circ} 39^{\prime} \mathrm{N}\right.$ latitude, $87^{\circ} 42^{\prime} \mathrm{E}$ longitude and at an elevation of $58.9 \mathrm{~m}$ above mean sea level), 
Palli Siksha Bhavana (Institute of Agriculture), Visva-Bharati, Sriniketan, West Bengal, India. The study was laid out in randomized complete block design comprising five hybrid rice varieties with four replications. Five rice hybrids - four Bayer's hybrids namely 6129 Gold, Tej Gold, 6444 Gold, Prima Gold and one hybrid check (PHB 71). 6129 Gold is India'sfirst BLB resistant short duration hybrid. Tej Gold performs well in moisture stress condition and 6444 Gold is highly suitable to direct seeded rice system. The hybrid PHB71 was released in 1997 by Pioneer Overseas Corporation (India branch) Andhra Pradesh, India. It was released for irrigated areas of Andhra Pradesh, Karnataka, Punjab, Haryana \& Western U.P. the hybrid is non-shattering type and resistant to blast, BPH \& gall midge.

12 days old seedlings were transplanted on beds with single seedlings at $25 \mathrm{~cm} \times 25 \mathrm{~cm}$ spacing for 6129 Gold and $30 \mathrm{~cm} \mathrm{x}$ $30 \mathrm{~cm}$ spacing for rest of the hybrids. The plots were supplied with well rotten FYM @ 10 tones $\mathrm{ha}^{-1}$ at the time first ploughing. Chemical fertilizers was applied @ 60-30-30 kg $\mathrm{N}-\mathrm{P}_{2} \mathrm{O}_{5}-\mathrm{K}_{2} \mathrm{O}$ ha ${ }^{-1}$, among which, $1 / 3 \mathrm{~N}$ and full $\mathrm{P}_{2} \mathrm{O}_{5}$ and $\mathrm{K}_{2} \mathrm{O}$ were applied as basal, rest of $\mathrm{N}$ was top-dressed in two equal levels at 21 and 42 days after transplanting (DAT). The hybrids 6129 Gold, Tej Gold were harvested at 90 DAT and other three hybrids were harvested at 100 DAT.

CGR (Crop Growth Rate), RGR (Relative Growth Rate), NAR (Net Assimilation Rate) and LAD (Leaf Area Duration) were calculated using the following formula:

$C G R=\frac{W_{2}-W_{1}}{T_{2}-T_{1}}($ Gardner 1985)

Where $\mathrm{W}_{2}$ and $\mathrm{W}_{1}$ were thedry weight at time $\mathrm{T}_{2}$ and $\mathrm{T}_{1}$.

$$
\begin{aligned}
& R G R=\frac{L n W_{2}-L n W_{1}}{T_{2}-T_{1}}(\text { Radford 1967). } \\
& L A D=\frac{L 1+L 2}{2}(\text { Wei et al., 2016) }
\end{aligned}
$$

Where $L_{1}$ and $L_{2}$ are leaf area at time $T_{1}$ and $T_{2}$ respectively

$$
\mathrm{NAR}=\frac{(\mathrm{W} 2-\mathrm{W} 1)(\log \mathrm{L} 2-\log \mathrm{L} 1)}{(\mathrm{t} 2-\mathrm{t} 1)(\mathrm{L} 2-\mathrm{L} 1)}(\text { Gardner } 1985)
$$

Where $\mathrm{W}_{2}$ and $\mathrm{L}_{2}$ are dry weight and leaf area respectively at time $\mathrm{T}_{2}$ and $\mathrm{W}_{1}$ and $\mathrm{L} 2$ are dry weight and leaf area respectively at time $T_{1}$.

$G D D=\frac{T_{\max }+T_{\min }}{2}-T_{b}$

Where Tmax and Tmin are maximum and minimum daily temperature. Tbase is threshold temperature of rice.

\section{$H T U=G D D \times B S S H$}

\section{Results and Discussion Growth attributes}

The hybrid rice varieties significantly differed in terms of crop growth rate, relative growth rate, net assimilation rate and leaf area duration. Crop growth rate measures the efficiency of crop per unit of land area. The crop growth rate was maximum at $60-90$ DAT. At initial growth stage $(30-$ 60 DAT), the variety 6129 Gold $\left(23.7 \mathrm{~g} \mathrm{~m}^{-2}\right.$ day $\left.^{-1}\right)$ recorded highest crop growth rate followed by PHB $71\left(20.1 \mathrm{~g} \mathrm{~m}^{-2}\right.$ day $^{-}$ $\left.{ }^{1}\right)$ and 6444 Gold $\left(19.6 \mathrm{~g} \mathrm{~m}^{-2} \mathrm{day}^{-1}\right)$. Whereas, the hybrid variety Prima Gold $\left(47.5 \mathrm{~g} \mathrm{~m}^{-2} \mathrm{day}^{-1}\right)$ reached peak in crop growth rate at later growth stage $(60-90$ DAT) followed by 6444 Gold (40.1 $\mathrm{g} \mathrm{m}^{-2}$ day $^{-1}$ ).

Relative growth rate of the hybrid rice varieties was found higher at initial growth period $(30-60$ DAT $)$. The relative growth rate was maximum in 6129 Gold $\left(0.069 \mathrm{~g} \mathrm{~g}^{-1}\right.$ day $\left.^{-1}\right)$ at $30-60$ DAT. Which was statistically at par with Prima Gold (0.065 $\left.\mathrm{g} \mathrm{g}^{-1} \mathrm{day}^{-1}\right)$ and PHB $71\left(0.063 \mathrm{~g} \mathrm{~g}^{-1} \mathrm{day}^{-1}\right)$. At later growth period, the higher relative growth rate was obtained with Prima Gold $\left(0.038 \mathrm{~g} \mathrm{~g}^{-1}\right.$ day $\left.^{-1}\right)$ followed by 6444 Gold $\left(0.033 \mathrm{~g} \mathrm{~g}^{-1}\right.$ day $\left.^{-1}\right)$ and Tej Gold $\left(0.033 \mathrm{~g} \mathrm{~g}^{-1} \mathrm{day}^{-1}\right)$.In case of crop growth rate, the variety 6129 Gold $\left(23.1 \mathrm{~g} \mathrm{~m}^{-2}\right.$ day $\left.^{-1}\right)$ recorded least crop growth rate at $60-90$ DAT.

Net assimilation rate represents plant photosynthetic efficiency. The trend of NAR was lower at initial growth stage $(30-60$ DAT $)$ and higher at later growth stage $(60-90$ DAT). Due to higher LAI at 60 DAT, the NAR was higher at that growth stage. Since 6129 Gold matured earlier, the NAR was higher at both $30-60$ and $60-90$ DAT among the five hybrid rice cultivars.

Leaf area duration followed the similar trend among the cultivars except 6129 Gold. Leaf area duration was higher at 60 - 90 DAT than at early growth stage. Among the hybrid rice cultivars, 6444 Gold noted maximum LAD during its entire growth period followed by Prima Gold which was statistically at par (Table 1).

At $60 \mathrm{DAT}$, the varieties stepped over vegetative growth stages, as a result the dry matter accumulation was less at that period. This study supports the findings of Rajput et al. (2017) ${ }^{[12]}$, who stated that crop growth rate, relative growth rate and net assimilation rate of rice varieties was highest at 60 - 90 DAT followed by 30 - 60 DAT grown under SRI. Thorne (1961) ${ }^{[17]}$ stated that RGR decreases due to shedding of lower leaves by upper leaves. Lower RGR in 6129 Gold in between 60-90 DAT than 30-60 DAT can be attributed to senescence of leaf in this early maturing variety (Awal 2000, Valero et al., 2005) ${ }^{[1,20]}$ whereas, onset of panicle initiation and higher green leaves in case of other varieties in between 60 to 90 DAT recorded higher RGR (Ko et al., 2017) ${ }^{[10]}$. Leaf area duration of 6129 Gold was also less in later growth stage due to the same reason as RGR.

\section{Yield attributes and yield}

The yield and yield attributing characters varied significantly among rice hybrid varieties except no. of filled grains per panicle (table 2). No. of hill $\mathrm{m}^{-2}$ ranged from 11.7 17.3.Among the five rice hybrid varieties, maximum no. of hills $\mathrm{m}^{-2}$ was obtained with 6129 Gold.Number of panicle $\mathrm{m}^{-2}$ varied to the tune of $195.1-215.5$. No. of panicles $\mathrm{m}^{-2}$ were maximum in 6129 Gold (215.5) which was statistically at par with Prima Gold (212.7) and 6444 Gold (210.8).Filled grain per panicle is an important yield determining character of rice. The present study revealed that the no. of filled grain per panicle varied from 186.9 - 212.4. There were no significant differences among the varieties in filled grain per panicle. Filled grain per panicle was also highest in 6129 Gold (212) followed by 6444 Gold (202), PHB 71 (199). 1000 grain weight varied between $23 \mathrm{~g}$ in 6129 Gold to $25 \mathrm{~g}$ for Prima Gold. Highest seed yield (table 3) was noted in medium to mid-late duration rice hybrid Prima Gold $\left(6.9 \mathrm{t} \mathrm{ha}^{-1}\right)$ being at 
par with 6444 Gold (6.8 $\left.\mathrm{t} \mathrm{ha}^{-1}\right)$ and PHB $71\left(6.7 \mathrm{t} \mathrm{ha}^{-1}\right)$. Lowest yield was recorded with Tej Gold (4.6 t ha-1).

The effect of no. of panicles $\mathrm{m}^{-2}\left(\mathrm{R}^{2}=0.913\right)$ and no. of filled grains panicle ${ }^{-1}\left(\mathrm{R}^{2}=0.530\right)$ on grain yield showed a positive polynomial relation with grain yield (Fig 1). Apart from the yield attributing characters, the associated yield parameters viz., panicle length $\left(\mathrm{R}^{2}=0.707\right)$, panicle weight $\left(\mathrm{R}^{2}=0.902\right)$ and percent filled grain $\left(\mathrm{R}^{2}=0.871\right)$ also showed a strong polynomial relation with grain yield (Fig. 2). Straw yield was also maximum in variety Prima Gold $\left(9.9 \mathrm{t} \mathrm{ha}^{-1}\right)$ followed by PHB 71 (8.3 $\left.\mathrm{t} \mathrm{ha}^{-1}\right)$ and 6444 Gold $\left(8.2 \mathrm{t} \mathrm{ha}^{-1}\right)$. Harvest index varied from 0.54 (6129 Gold) to 0.40 (Prima Gold). The accumulated GDD $\left(\mathrm{R}^{2}=0.875\right)$ and HTU $\left(\mathrm{R}^{2}=0.875\right)$ of the five rice hybrid cultivars showed a positive linear relation with yield (Fig 3 and 4).

Lowest 1000 grain weight might be the reason of comparatively lower yield of 6129 Gold than Prima Gold and 6444 Gold instead of having higher no. of panicles $\mathrm{m}^{-2}$ and filled grain panicle ${ }^{-1}$. Similarly heavier grains (highest 1000 grain weight) coupled with a good number of panicle $\mathrm{m}^{-2}$ and filled grain per panicle attributed to highest grain yield in Prima Gold. Higher yield also can be assigned with efficient resource utilization, less inter and intra plant competition and differences in heterosis. Salgotra (2005) [13] observed significant heterosis for grain yield among hybrids when tested the performance of eight rice hybrids. Uphoff (2004) ${ }^{[18]}$ reported more than $15 \mathrm{t} \mathrm{ha}^{-1}$ yield from SRI with hybrid varieties whereas it was 6-12 $\mathrm{t} \mathrm{ha}^{-1}$ from traditional varieties under same set of management practice in Madagascar. Satyanaryan (2004) [14] and Jiaguo (2004) ${ }^{[8]}$ evidenced superiority of rice hybrids with respect to straw yield. Prima Gold showed lowest harvest index as the straw yield was highest.

\section{Grain quality}

Highest hulling percentage was recorded with 6444 Gold $(75.1 \%)$ closely followed by Prima Gold $(73.5 \%)$. Whereas Prima Gold $(71.0 \%)$ registered maximum milling percentage followed by 6444 Gold (70.6\%) and PHB 71(68.0\%) and lowest was recorded with 6129 Gold (64.2\%). Head rice recovery also maintained the same trend like milling percentage i.e. highest value was recorded with Prima Gold (96.5\%) followed by 6444 gold and PHB 71 (table 4).

The results obtained regarding grain quality were harmonious to the report stated by Choudhary et al. (2013) ${ }^{[2]}$ who reported $81 \%, 66.8 \%$ and $56.0 \%$ hulling percentage, milling percentage and head rice recovery in PHB 71 respectively.

Table 1: Growth attributes of hybrid rice varieties

\begin{tabular}{|c|c|c|c|c|c|c|c|c|}
\hline \multirow[t]{2}{*}{ Variety } & \multicolumn{2}{|c|}{$\begin{array}{l}\text { Crop growth rate } \\
\left(\mathrm{g} \mathrm{m}^{-2} \mathbf{d a v}^{-1}\right)\end{array}$} & \multicolumn{2}{|c|}{$\begin{array}{l}\text { Relative growth rate } \\
\left(\mathrm{g} \mathrm{g} \mathrm{g}^{-1} \text { day }^{-1}\right)\end{array}$} & \multicolumn{2}{|c|}{$\begin{array}{l}\text { Net assimilation rate } \\
\left(\mathrm{g} \mathrm{m}^{-2} \mathrm{day}^{-1}\right)\end{array}$} & \multicolumn{2}{|c|}{ Leaf area duration } \\
\hline & 30-60 DAT & 60-90 DAT & 30-60 DAT & 60-90 DAT & 30-60 DAT & 60 - 90 DAT & 30-60 DAT & $60-90$ DAT \\
\hline H1: 6129 Gold & 23.7 & 23.1 & 0.069 & 0.020 & 0.016 & 0.018 & 73.0 & 65.2 \\
\hline H2: Tej Gold & 18.2 & 35.5 & 0.062 & 0.033 & 0.009 & 0.017 & 75.3 & 75.7 \\
\hline H3: 6444 Gold & 19.6 & 40.1 & 0.060 & 0.033 & 0.008 & 0.013 & 89.3 & 103.3 \\
\hline H4: Prima Gold & 19.0 & 47.5 & 0.065 & 0.038 & 0.008 & 0.016 & 81.5 & 99.6 \\
\hline H5: PHB 71 & 20.1 & 38.9 & 0.063 & 0.032 & 0.009 & 0.015 & 76.2 & 89.0 \\
\hline S.Em $( \pm)$ & 1.00 & 1.85 & 0.002 & 0.002 & 0.0004 & 0.0013 & 2.25 & 3.66 \\
\hline CD 5\% & 3.03 & 5.65 & 0.007 & 0.005 & 0.0012 & 0.0039 & 6.93 & 11.29 \\
\hline
\end{tabular}

Table 2: Yield attributes of hybrid rice varieties grown under SRI

\begin{tabular}{|c|c|c|c|c|}
\hline Variety & Hills m $^{-2}$ & $\begin{array}{c}\text { No of } \\
\text { panicles } \mathbf{~ m}^{-2}\end{array}$ & $\begin{array}{c}\text { Filled grain }_{\text {panicle }^{-1}} \\
\text { peo0 grain } \\
\text { weight(g) }\end{array}$ \\
\hline H1: 6129 Gold & 17.3 & 215.5 & 212.4 & 22.6 \\
\hline H2: Tej Gold & 11.7 & 195.8 & 186.9 & 23.6 \\
\hline H3: 6444 Gold & 11.7 & 210.8 & 202.0 & 23.5 \\
\hline H4: Prima Gold & 11.7 & 212.7 & 192.5 & 25.0 \\
\hline H5: PHB 71 & 11.7 & 195.1 & 198.7 & 23.3 \\
\hline S.Em ( \pm ) & 0.56 & 4.4 & 6.3 & 0.16 \\
\hline CD 5\% & 1.72 & 13.5 & NS & 0.49 \\
\hline
\end{tabular}

NS: Non significant
Table 3: Grain yield, straw yield and harvest index of hybrid rice varieties grown under SRI

\begin{tabular}{|c|c|c|c|}
\hline Variety & $\begin{array}{c}\text { Grain yield } \\
\quad\left(\mathrm{t} \mathrm{ha}^{-1}\right)\end{array}$ & $\begin{array}{c}\text { Straw yield } \\
\left(\mathrm{t} \mathrm{ha}^{-1}\right)\end{array}$ & $\begin{array}{c}\text { Harvest } \\
\text { Index }(\mathrm{HI})\end{array}$ \\
\hline H1: 6129 Gold & 5.6 & 4.5 & 0.54 \\
\hline H2: Tej Gold & 4.6 & 5.9 & 0.41 \\
\hline H3: 6444 Gold & 6.8 & 8.2 & 0.45 \\
\hline H4: Prima Gold & 6.9 & 9.9 & 0.40 \\
\hline H5: PHB 71 & 6.7 & 8.3 & 0.44 \\
\hline S.Em $( \pm)$ & 0.27 & 0.41 & 0.011 \\
\hline CD 5\% & 0.84 & 1.25 & 0.035 \\
\hline
\end{tabular}

Table 4: Hulling (\%), milling (\%) and head rice recovery (\%) of hybrid rice varieties grown under SRI

\begin{tabular}{|c|c|c|c|}
\hline Variety & Hulling \% & Milling \% & Head rice \% \\
\hline H1: 6129 Gold & $8.48(72.0)$ & $8.01(64.2)$ & $9.44(89.2)$ \\
\hline H2: Tej Gold & $8.41(70.8)$ & $8.08(65.3)$ & $9.61(92.3)$ \\
\hline H3: 6444 Gold & $8.66(75.1)$ & $8.40(70.6)$ & $9.70(94.2)$ \\
\hline H4: Prima Gold & $8.57(73.5)$ & $8.42(71.0)$ & $9.83(96.5)$ \\
\hline H5: PHB 71 & $8.52(72.6)$ & $8.25(68.0)$ & $9.68(93.7)$ \\
\hline S.Em $( \pm)$ & 0.08 & 0.90 & 0.06 \\
\hline CD 5\% & NS & 0.28 & 0.20 \\
\hline
\end{tabular}

Square root transformed data. Data in parenthesis are original mean. 


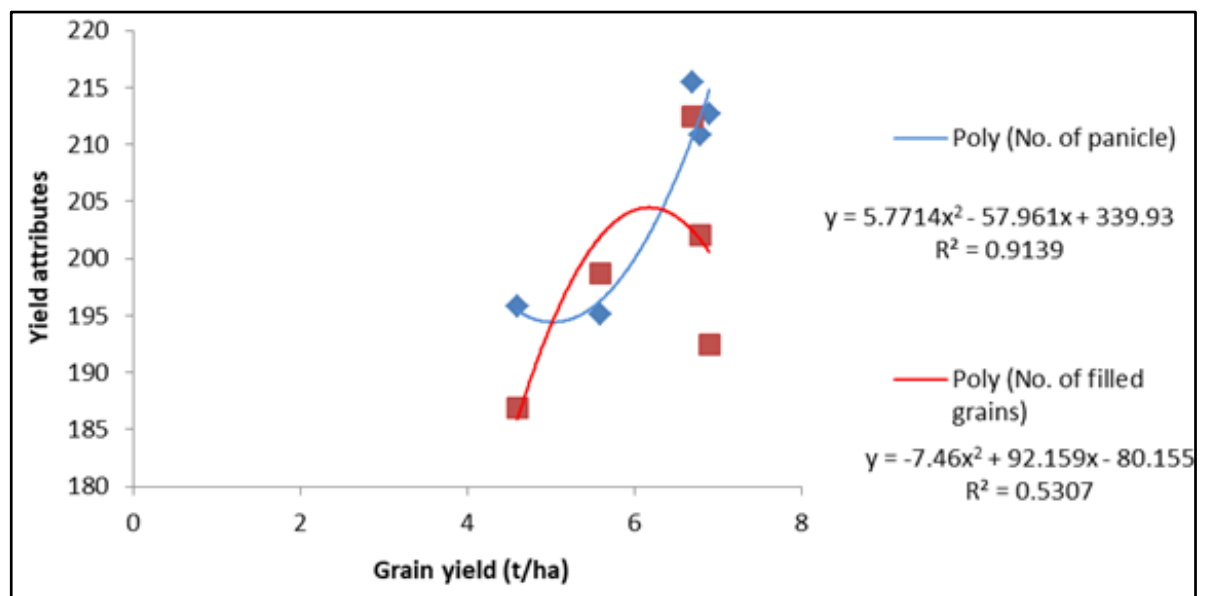

Fig 1: Relation between no. of panicle $\mathrm{m}^{-2}$ and no. of filled grain panicle ${ }^{-1}$ with grain yield

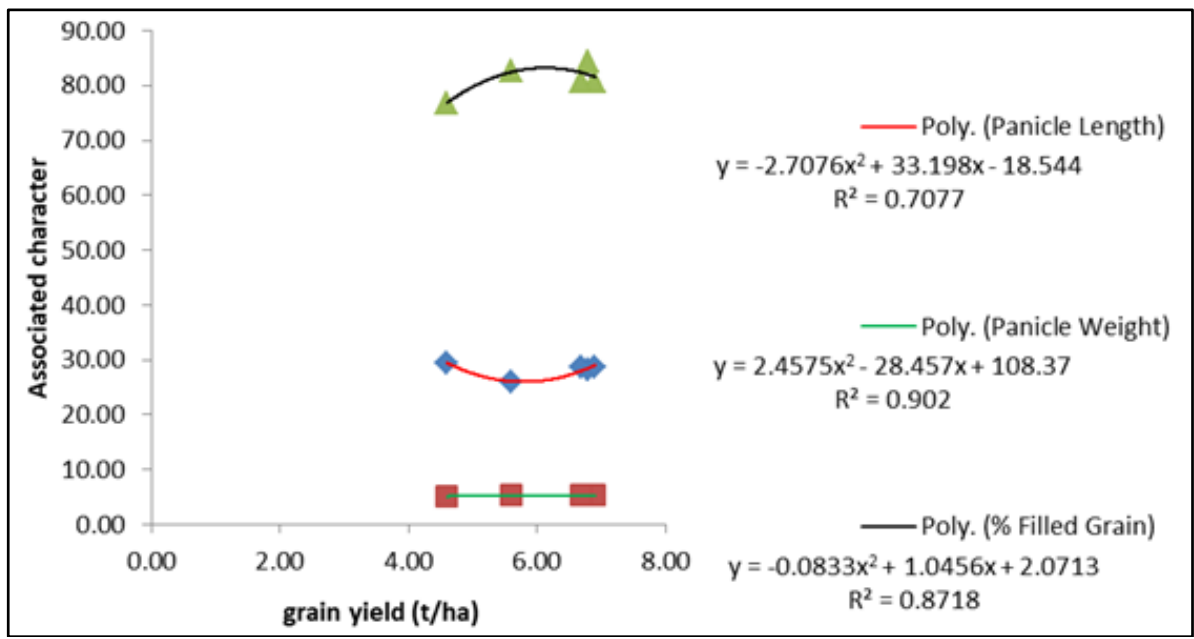

Fig 2: Relation among panicle length, Panicle weight and \% filled grain with grain yield

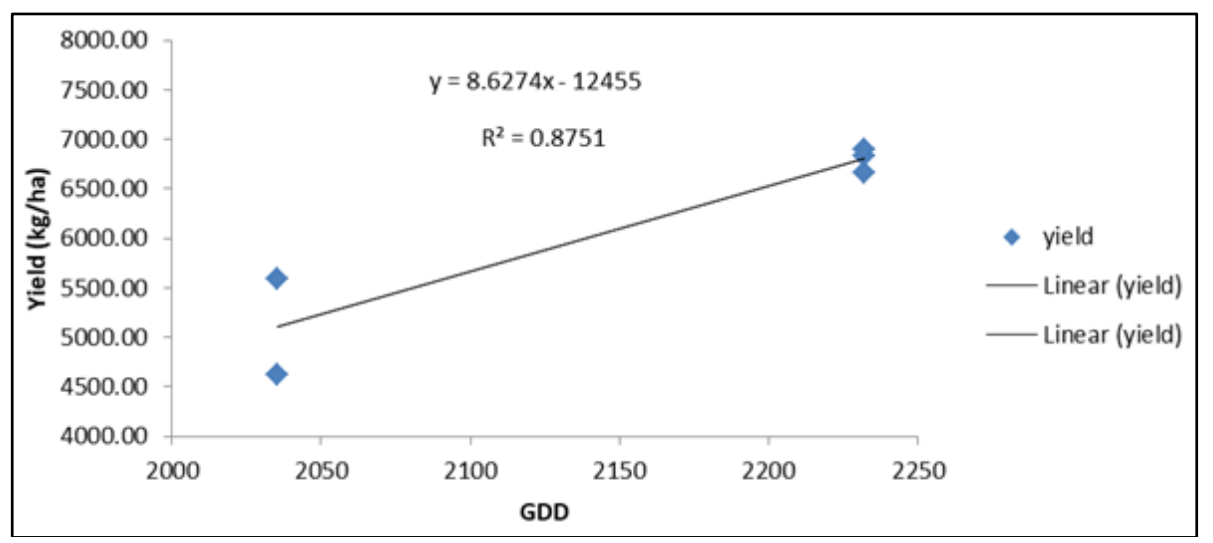

Fig 3: Relation between Yield (kg/ha) and GDD

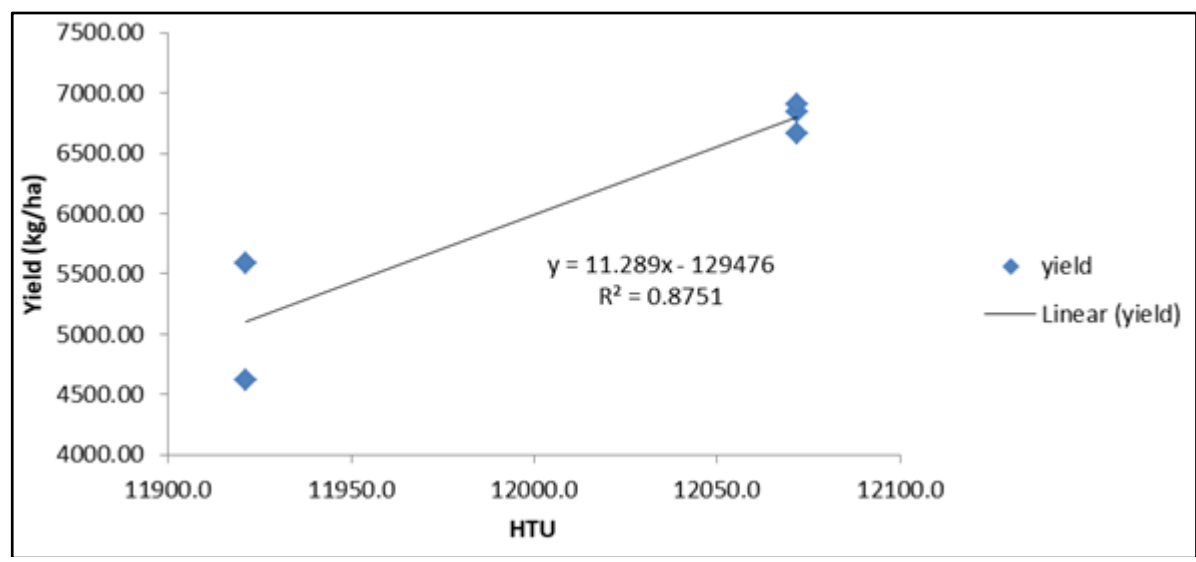

Fig 4: Relation between Yield (kg/ha) and HTU

$\sim 1839 \sim$ 


\section{Conclusion}

Comparing the performance of these hybrid rice varieties in terms of growth attributes, yield attributes, yield and grain quality, it was evident from the study that Prima Gold and 6444 Gold performed better under the moisture stress red laterite zone of West Bengal.

\section{References}

1. Awal MA, Khan MAH. Mulch Induced EcoPhysiological Growth and Yield of Maize. Pakistan Journal of Biological Sciences. 2000; 3:61-64.

2. Choudhary RL, Kumar D, Shivay YS, Anand A, Nain L. Yield and quality of rice (Oryza sativa) hybrids grown by SRI method with and without plant growth promoting rhizobacteria. Indian Journal of Agronomy. 2013; 58(3):430-433.

3. DES. Agricultural statistics at a glance 2017-18. Directorate of Economics and Statistics, Department of Agriculture and Co-operation, Ministry of Agriculture, Government of India, 2018, 3.

4. Devi KS, Ponnarasi T. Agricultural Economics Research Review. 2009; 22:341-347.

5. Gardner FP, Pearce RB, Mitchell RL. Physiology of Crop Plants. Iowa State University, Ames, 1985; 31-36.

6. Ghosh A, Das S, Reja MH, Maity SK. Comparative Study of Energy Utilization and Green House Gas Emission by Hybrid Rice Grown under Two Different Cultivation Systems in Red Lateritic Zone of West Bengal. International Journal of Environment and Climate Change. 2019; 9(6):356-363.

7. Haloi B, Baldev B. Effect of irrigation on growth attributes in chickpea when grown under different dates of sowing and population pressure. Indian J. Plant Physiol. 1986; 29:14-27.

8. Jiagua Z. SRI yield increased by farmers producing currently at low levels. Sichaun Academy of Agriculture Science, Chengdu, China, September, 2004.

9. Kabir H, Uphoff N. Result of disseminating SRI with farmers field. Experiment Agril. 2007; 43(4).

10. Ko KMM, Hirai Y, Zamora OB, de Guzman LE. Agronomic and Physiological Responses of Rice (Oryza sativa L.) under Different Water Management Systems, Fertilizer Types and Seedling Age. American Journal of Plant Sciences. 2017; 8:3338-3349.

11. Radford PJ. Growth analysis formulae: their use and abuse. Crop Sci. 1967; 7:171-175.

12. Rajput A, Rajput SS, Jha G. Physiological parameters leaf area index, crop growth rate, relative growth rate and net assimilation rate of different varieties of rice grown under different planting geometries and depths in SRI. International Journal of Pure \& Applied Bioscience. 2017; 5(1):362-367.

13. Salgotra RK, Katoch PC, Sood M. Performance of rice hybrids for yield and quality traits in mid hills of Himachal Pradesh, India. 2005; 42(2):93-96.

14. Satyanarayana A. SRI is more resistant to other biotic and abiotic stress besides drought. Acharya NG. Ranga Agricultural University, Hyderabad, India, February, 2004.

15. Satyanarayana A, Thiyagarajan TM, Uphoff N. Opportunities for water saving with higher yield from the system of rice intensification. Irrigation Science. 2007; 25:99-115.

16. Stoop WA, Uphoff N, Kassam A. A review of agricultural research issues raised by the System of Rice
Intensification (SRI) from Madagascar: Opportunities for improving farming systems for resource poor farmers. Agricultural Systems. 2002; 71:249-274.

17. Thorne GN. Effects of age and environment on net assimilation rate of barley. Ann. Bot. 1961; 25: 29-38.

18. Uphoff N. System of rice intensification responds to $21 \mathrm{st}$ century needs. Rice Today. 2004; 42:3-3.

19. Uphoff N, Randriamiharisoa R. Reducing water use in irrigated rice production with the Madagascar System of Rice Intensification (SRI). In: Water-Wise Rice Production. International Rice Research Institute, Los Baños, Philippines, 2002, 71-87.

20. Valero A, De J, Maturano M, Ramírez AA, Tarjuelo JM, Martín-Benito et al. Growth and Nitrogen Use Efficiency of Irrigated Maize in a Semiarid Region as Affected By Nitrogen Fertilization. Spanish Journal of Agricultural Research. 2005; 3:134-144.

21. Verma AK, Pandey N, Shrivastava GK. Production potential and economics of hybrid rice under system of rice intensification and its manipulation. SAARC J. Agri. 2014; 12(2):71-78.

22. Wanjari RH, Mandal KG, Ghosh PK, Adhikari T, Rao NH. Rice in India: Present status and strategies to boost its production through hybrids. Journal of Sustainable Agriculture. 2006; 28(1):19-39. 